\title{
SMALL-SCALE RENEWABLE ENERGY SYSTEMS IN THE DEVELOPMENT OF DISTRIBUTED GENERATION IN POLAND
}

\author{
Justyna CHODKOWSKA-MISZCZUK
}

\begin{abstract}
Small-scale renewable energy systems in the context of the development of distributed generation, are discussed for the case of Poland. A distributed energy system is efficient, reliable and environmentally friendly, and is one of the most recent trends in the development of the energy sector in Poland. One of the important dimensions of this process is the creation of micro- and small-power producers based on renewable, locally-available energy sources. It is clear that the development of small-scale renewable energy producers takes place in two ways. One of these is through small hydropower plants, which are the aftermath of hydropower development in areas traditionally associated with water use for energy purposes (northern and western Poland). The second is through other renewable energy sources, mainly biogas and solar energy and located primarily in southern Poland, in highly urbanized areas (e.g. Ślaskie Voivodship). In conclusion, the development of small-scale renewable energy systems in Poland is regarded as a good option with respect to sustainable development.
\end{abstract}

\section{Shrnutí}

\section{Malo-měřítkové systémy obnovitelné energie v rozvoji rozptýlené výroby v Polsku}

Článek pojednává o malo-měřitkových systémech obnovitelné energie v kontextu rozvoje rozptýlené výroby $v$ Polsku. Systém rozptýlené produkce je efektivní, spolehlivý a šetrný $k$ životnímu prostredí a je jedním $z$ nejnovějšich trendů rozvoje energetického sektoru v Polsku. Jednou z důležitých dimenzí tohoto procesu je vznik mikro a malovýrobců na bázi obnovitelných, lokálně dostupných zdrojů. Malo-měřítková produkce obnovitelné energie se rozviji dvěma směry. Pruní je prostřednictvím malých vodních elektráren, které jsou pokračovatelem rozvoje vodni energie $v$ oblastech tradičně spojených s využíváním vody pro energetické účely (severní a západní Polsko). Druhý je prostřednictvím dalších obnovitelných zdrojů, zejména bioplynu a sluneční energie, převážně ve vysoce urbanizovaných oblastech jižního Polska (Slezské vojvodství). Z článku vyplývá, že malo-měřitkové systémy výroby obnovitelné energie jsou vhodnou volbou z hlediska trvale udržitelného rozvoje.

Key words: distributed generation, small-scale renewable energy, Poland

\section{Introduction}

The socio-economic development of a country is determined principally by both the production of and demand for electricity. In today's world, as many as 2 billion people have no access to electricity, of which $98 \%$ live in developing countries (Suberu et al., 2013). Energy security is equally important for post-communist countries that are still in the process of economic transition. One of these countries is Poland, where the domination of obsolete power stations and power grids is accompanied by a steadilyexpanding demand for electrical energy. The Polish Energy Group (Polska Grupa Energetyczna) estimates that in the years to come, the demand for electricity will be increasing in Poland at a rate of $1-1.7 \%$ per year (www.ure.gov.pl). As a European Union (EU) Member State, Poland is also required to modernize its power sector in line with the laws in force. European policymakers are expressing clear political support for a move to a low-carbon society. The expected changes range from a wider use of renewable energy sources and improved energy efficiency, to reduced emission of $\mathrm{CO}_{2}$ (known as the 20-20-20 targets) and decarbonization energy sector by 2050 (Klose et al., 2010; Ruester et al., 2013). Given the urgency of these regulations, including carbon emission reductions, Poland faces a major challenge in its energy sector. Taking into account electricity production in Poland, over $85 \%$ is based on a coal (both hard coal and brown coal), while renewable energy sources provide less than $10 \%$ (Statystyka Elektroenergetyki Polskiej, 2012).
A relatively limited supply of electricity in Poland in the near future may emerge, even though some modernisation works and new projects, although to an insufficient degree, have been launched and there are some on-going deregulation processes in the power sector. The Energy Regulatory Office (ERO) estimates that after 2015, Poland may be short of as much as 5,000 MW. One solution to this huge problem for the country's economy is distributed generation, based on local renewable sources of energy, which is more efficient than a centralised system (Moriarty, Honnery, 2011). As planned, in Poland, the expansion of domestic micro generation systems is to generate $1.9 \mathrm{GW}$ of new power by 2020 (http:// biogazownierolnicze.pl).

In the face of this on-going process of transformation of the energy sector in Poland, including the development of distributed generation, there is a need to enumerate and evaluate the current situation. This is because, in Poland, where the energy sector is highly centralized and the issue of distributed generation is still new, there is a need for research considering the current use of small-scale renewable energy. Furthermore, an extremely important context for these studies is to establish the first legal regulations to support electricity production via microinstallations, i.e. the law known as the Energy Three Pack. Another good reason to address this issue is the lack of this kind of research related to the situation in Poland. This is especially important because this problem is a part of a wider scientific and public discussion about the 
possibilities, directions and conditions for the development of distributed generation and energy production in smallscale installations.

The aim of this article, then, is to outline and evaluate the current situation regarding micro- and small-renewable energy systems in the context of distributed generation, the popularity of which has been recently growing in Poland. This objective will be achieved by analysing the electricity production from energy sources such as water, wind, solar radiation and biogas in small-scale installations (to $200 \mathrm{~kW}$ ); according to Polish law the total installed electrical capacity of a small-scale installation is not higher than $200 \mathrm{~kW}$ (Ustawa z dnia 26 lipca 2013). The purpose is to indicate the most prospective renewable energy sources that may be most appropriate for electricity production in small-scale installations in Poland. In addition, the aim is to identify regions in Poland with the greatest potential for distributed generation development, in relation to small-scale renewable energy systems. A final aim is to identify the possibility of using solar energy in urban and suburban areas, such as the supply of thermal energy in multi-family buildings and single family-houses.

This research project is based on the Energy Regulatory Office data on small-scale renewable energy systems generating electricity in Poland (as of 31 July 2013). The Energy Regulatory Office is the government institution which carries out assignments relating to the power sector in Poland, including electricity production. As a government agency, it has reliable and complete data on electricity production in small-scale renewable energy systems.

This study is carried out at the poviat ${ }^{1}$ level, but some research results are presented at the voivodship ${ }^{2}$ level. Moreover, based on a case study, the production of thermal energy from solar energy is analysed. The generation of thermal energy is illustrated by a case study of solar technologies applied to multi-family buildings managed by housing cooperatives in Bydgoszcz and Torun (the two major cities of Kujawsko-Pomorskie Voivodship) as of 2012. These cities (Bydgoszcz and Torun) were among the first in Poland where solar technologies were applied to multi-family buildings. The experiences of these cities can be very useful in other similar projects, especially in the context of using the small-scale installations in thermal energy production.

\section{Distributed generation - the concept and main issues}

Currently, the energy system is based on particular assumptions related to sustainable development. In accordance with the principles of the contemporary energy hierarchy the priority is energy conservation, the next is sustainable production (primarily from renewables), and the lowest option is energy generation from fossil sources. In this context, distributed generation enables the implementation of the main objectives of a sustainable energy system, including improving energy efficiency, increasing the use of renewable energy sources and reducing energy production from fossil sources (Wolfe, 2008). Generally, distributed generation (DG) includes the generation of electrical energy, thermal energy and liquid fuels based on decentralised small-scale power technologies serving mainly local needs
(Energetyka rozproszona, 2011). It must be noted that there are many definitions of distributed generation (Ackermann et al., 2001; El-Khattam and Salama, 2004; Pepermans et al., 2005; Purchala et al., 2007; Wolfe, 2008). On the one hand, distributed generation is defined in terms of generation capacity (cf. Dondi et al., 2002). On the other hand, a definition of distributed generation refers to connection and location (cf. Ackermann et al., 2001). Generally, definitions suggest that small-scale generation units connected to the distribution grid are to be considered as part of distributed generation. Besides, generation units installed close to the load or at the customer side of the meter are also commonly identified as distributed generation (Pepermans et al., 2005).

Considering generation capacity, distributed generation is a small source of power - typically ranging from less than one $\mathrm{kW}$ to tens of MW (Dondi et al., 2002), including, for example, 30 MW (Chambers, 2001). Generally, in Poland distributed generation utilises power generation systems of installed power capacity to around $200 \mathrm{~kW}$. The systems are subdivided into micro systems (of the total installed capacity (electrical and thermal) of, respectively, $40 \mathrm{~kW}$ and $70 \mathrm{~kW}$ ) and small systems (installed electrical capacity of 40-200 kW and thermal capacity of 70-300 kW (Więcka et al., 2012), which are the most frequently used by households, farms and small firms. Their operators can sell the generated power and/or utilise it to meet their own needs. People who use small-scale renewable energy systems to produce energy as well as consuming their output are called prosumers. Their current population in Poland exceeds 220,000, with every second Pole declaring their interest in the systems, mainly in technologies allowing the energy of solar radiation to be converted into power (http://biogazownierolnicze.pl).

DG was the most common solution in the early period of the global power industry, i.e. in the late $19^{\text {th }}$ century. Over time, however, it started giving way to centralised power generation. As a result, by the end of the $20^{\text {th }}$ century DG systems were mainly used for back-up purposes or by small, autonomous off-grid users. Between the early $20^{\text {th }}$ century and 1990 the percentage of independent power producers (IPPs) decreased in the world market ten times, from around $30-40 \%$ to 3-4\% (Energetyka rozproszona, 2011).

At the end of the $20^{\text {th }}$ century, the significance of IPPs for the global, and also European power industry slowly started to grow following the implementation of deregulation processes in the world markets (Carley, 2009), a trend that can be observed in Poland too. According to Bell and Cloke (1990), deregulation resembles liberalisation and consists of the withdrawal of government control over various sectors of the economy, including the power industry. The process aims to create a competitive market for power, now recognised as a commodity. Because a market cannot be really competitive without a diverse ownership structure of the players, incentives for the establishment of IPPs are created, etc. (Luchter, 2001). An equally important aspect of deregulation is that it drives the diversification of energy sources, such as a wider use of locally available sources of renewable energy.

All these changes lead to the emergence of smallscale renewable energy systems (Solomon et al., 2006). Nevertheless, deployment of small-scale renewable energy systems has so far progressed slowly in Poland, as in other post-communist countries such as Lithuania (Miskinis

\footnotetext{
${ }^{1}$ poviat - administrative region of the $2^{\text {nd }}$ order

2 voivodship - administrative region of the $1^{\text {st }}$ order
} 
et al., 2011). The Polish energy market is still dominated by centralized generation (over 90\% of the energy market for electricity) (Energetyka rozproszona, 2011).

Development of distributed generation - as a part of the energy system - is conditioned by particular implementations noted on the stage of energy production, distribution and legal regulation. The first issue is to indicate the most promising renewables, which can be used in distributed generation. The further consequences refer to the technological and infrastructural aspects of energy production and distribution, including energy transport, storage and networks (Woodman and Baker, 2008; Wolfe, 2008; Barry, Chapman, 2009; Wolsink, 2012). For instance, in the context of energy transport there is the question related to the connection of individual energy users to the national energy system (Pecas Lopes et al., 2007; Wolfe, 2008). Apart from distributed generation and energy storage, another aspect of a decentralised energy system is a more active involvement of consumers through demand response. Demand response does not necessarily save energy, but rather shifts energy loads around in time. This is very important since it potentially avoids the need to shed excess energy supply at times of low demand or high supply (Decentralised Energy Systems, 2010). In addition an increasingly decentralised energy system could offer substantial opportunities for the storage of energy (including on-site energy storage options) and reducing energy losses (Wolfe, 2008; Basak et al., 2012).

The distribution networks will also have to evolve increasingly towards smart grids (Jiayi, XuRong, 2008; Wolfe, 2008; Barry, Chapman, 2009; Wolsink, 2012; Zhang et al., 2014). Smart grids are active and dynamic electricity networks where the smart grid functions as a facilitator for active end-users as opposed to the traditional passive topdown (uni-directional, producer-to-consumer) power system (Decentralised Energy Systems, 2010). At the same time it can facilitate the achievement of a renewable electricity future by integrating distributed renewable resources locally, while providing greater flexibility for managing resources to respond to varying grid conditions (Newcomb et al., 2013).

It is also necessary, however, to develop an effective and innovative business model as an additional tool to support the process of a decentralised energy system (Gordijn, Akkermans, 2007; Klose at al., 2010; Eghtedarpour, Farjah, 2012; Richter, 2013), including supply demand models, regional models, resource models and the application of energy management systems (Jebaraj, Iniyan, 2006; Hiremath et al., 2007; Basak et al., 2012; Herran, Nakata, 2012). The one of the essential conditions for increasing the use of renewables is also social acceptance of renewable energy, for instance wind energy (Frantál, Kunc, 2011).

It should be mentioned that in Poland, as in other countries, besides the infrastructural and technological implications related to a decentralised energy system, an important factor restricting the development of distributed generation is unstable energy policy. Many researchers emphasize (cf. Barry and Chapman, 2009; Wolfe, 2008; Vogel, 2009; Rydin et al., 2011) that only if policy support is provided, will smallscale renewable energy systems be able to play a useful role in the power sector.

Renewable energy technologies, including small-scale systems, are a relatively recent innovation for the planning system and have placed new demands on policy guidance at national and local levels. Both government and local policies for renewables are still evolving (Hull, 1995), especially since (EU) Member States are required to modernize the power sector in line with the laws in force, which means a wider use of renewable energy sources and improved energy efficiency to reduced emission of $\mathrm{CO}_{2}$. It is difficult for countries where the energy sector is highly centralized and mostly coal-based (as in Poland). In such cases, the modernization of the power sector might be related to the increased use of renewable energy sources as well as clean coal technology. Clean coal technology, which could be one of the key ways to reduce greenhouse gas emissions, might enable fossil fuels to remain an integral part of the energy mix in the EU (The Future of Carbon Capture and Storage in Europe, 2013). It should be mentioned that many industrialized countries have achieved limited success in addressing their reliance on fossil fuels (Cirone, Urpelainen, 2013). According to the International Energy Agency (IEA), in 2010 less than 60\% of the IEA energy efficiency recommendations were implemented (even in these countries that are most proactive on energy).

The effects of renewable electricity policies are more pronounced before 1996 as well in developed and emerging countries. Moreover, policy effectiveness varies by the type of renewable electricity policy and energy source. The main barrier for the development of a renewable energy system is its high fixed costs (privately, unprofitable) compared to non-renewable electricity, including clean coal technologies (Verrbrugen et al., 2010; Aalarbes et al., 2013). As a result, only investment incentives and feed-in tariffs are found to be effective in promoting the development of all types of renewable energy sources for electricity (also distributed and micro generation) (Steenblik, Coroyannakis, 1995; Dong, 2012; Zhao et al., 2013). Besides, a large presence of non-governmental organizations and green residential customers facilitate the transmission of renewable energy policies (Delmas, Montes-Sancho, 2011; Stokes, 2013). There is a need for coalitions, mediators and proponents of renewables projects (Stokes, 2013).

Furthermore, decentralisation of the energy system is also a challenge for system planning and the management of energy infrastructure. A central government cannot direct this process although it can seek to provide incentives. The onus for promoting, delivering and coordinating energy decentralisation is likely to fall on local government. Because they tend to be smaller, decisions can be taken quickly and their structure can adapt more quickly to new situations, as compared to larger and more bureaucratic national governments (Puppim de Oliveira, 2009). A major role for local planning will be to monitor the evolving nature of energy decentralisation in their areas, looking across public, private and third sector schemes and taking a broad view of energy systems as encompassing generation, distribution and consumption (Rydin et al., 2011).

In Poland, energy policy is being transformed, as national laws are adapted to European Union regulations. One of the dimensions of this process is the government document "Energy Policy of Poland until 2030" (Polityka energetyczna Polski do 2030 r.). According to the "Energy Policy...", the development of the Polish energy sector includes the diversification of energy sources (increased use of renewable energy sources) and the use of clean coal technologies. Furthermore in this document DG development is treated as a central factor in the improvement of the country's energy efficiency. In addition, in July 2013, the national regulations related to the energy sector were partly amended (through the law known as the Energy Three Pack). The Energy Three- 
Pack is mainly aimed at implementing into the Polish legal system the provisions of the so-called Gas Directive (2009/73/ EC) and the Electricity Directive (2009/72/EC). Although the main part of the Energy Three Pack is dedicated to gas market regulations, it sets out the support scheme for small and micro renewable energy installations (i.e. energy sources with total installed electrical capacity not higher than $200 \mathrm{~kW}$, interconnected to the grid below $110 \mathrm{~kW}$, or of the total installed heat capacity not higher than $600 \mathrm{~kW})$. It must be noted that the act introduced preferential conditions for connection to the national grid micro-installations (less than $40 \mathrm{~kW}$ ). In accordance with the law, the owners of micro-installations of electricity production do not need formalize economic activities related to the electricity production, which means that they are exempt from the obligation to establish and run the business. Besides, this electricity will be bought at a price equal to $80 \%$ average selling prices of electricity in the previous year (Ustawa $\mathrm{z}$ dnia 26 lipca 2013). These rules allow for the creation of the financial support for the development of micro-installations, such as PV or wind turbines. It must be noted that this line of power sector development has also been incorporated in the draft of the new law on renewable energy sources.

The development of DG provides a range of benefits to the local economy, communities and the national power sector (Zahedi, 1996; Ackermann et al., 2001; Barry, Chapman, 2009; Encouraging Renewable Energy Development, 2011; Herran, Nakata, 2012). A. Lovins et al. (2002) have compiled a list of more than 200 benefits (social, economic, ethical and psychological, etc.). According to the aforementioned forecasts, a wider use of DG may cut the present consumption of energy by $20 \%$ in the EU alone (Bańkowski, Żmijewski, 2012). Moreover, DG following from the implementation of sustainable development principles, also promotes environmental protection and proenvironmental attitudes (Watson, 2004; Alanne, Saari, 2006; Akorede, Pouresmaeil, 2010; Kaygusuz et al., 2013).

\section{Micro and small renewable energy systems and production of electricity in Poland}

The total installed capacity of micro and small renewable energy systems in Poland accounts for $0.25 \%$ of the total installed capacity in Poland (www.ure.gov.pl). The average installed capacity of $84.2 \mathrm{~kW}$ per system shows that most of them are small (from 40 to $200 \mathrm{~kW}$ ). There are differences in the spatial distribution of micro and small systems in Poland. They are present in over $63 \%$ of rural poviats and in almost $34 \%$ of cities with poviat status. In northern voivodships and in the Opolskie Voivodship they generate power in more than $85 \%$ of rural poviats, but in the Mazowieckie, Podlaskie and Wielkopolskie Voivodships their rates do not exceed $40 \%$ (see Fig. 1).

The micro and small systems are least common in areas where electricity shortages occur already today - in northeastern Poland. The environmental and socio-economic conditions (low density of population, a considerable proportion of rural areas, etc.) make this part of the country one of the most conducive to the development of distributed generation. The relatively low number of microand small-systems in the Wielkopolskie Voivodship is due to the prevalence of large-scale renewable energy facilities, including wind power plants.

When the segment of micro and small electrical energy producers in Poland is analysed by source of renewable energy, we find that the sources of energy driving its development include the energy of water, wind and solar radiation, and biogas.

As far as the first source of energy, water, is concerned, small hydropower plants prevail and, unlike large hydropower facilities that have been steadily losing their position as providers of electrical energy since c. 2005 (ChodkowskaMiszczuk, Szymańska, 2011), they play an important role. A strong indication of this is their presence in over $45 \%$ of all Polish rural poviats and in $87 \%$ of poviats where small-scale renewable energy systems are used. Most of these areas have a long-standing tradition of harnessing the energy of rivers, dating back to the period of the Prussian partition, i.e. the turn of the $19^{\text {th }}$ and $20^{\text {th }}$ centuries (Luchter, 2000).

Although hydropower plants constitute a majority of smallscale facilities, they only represent just over $40 \%$ of the total installed capacity of all micro- and small-renewable energy systems in Poland. This is the case because over $30 \%$ of the analysed hydropower plants are micro-hydro systems (of installed capacity to $40 \mathrm{~kW}$ ); the average installed capacity of the considered hydropower plants is $70.4 \mathrm{~kW}$. Hence the installed capacity of micro and small hydropower systems stands at $0.5 \%$ of the installed capacity of all hydropower plants in Poland.

It is important to note that small hydropower plants not only perform social and economic functions (create jobs, generate electricity, attract tourists), but also enormously benefit the natural environment because of their water retention function.

Another source of renewable energy utilised by the micro and small systems is biogas (obtained from dump sites and sewage treatment plants). Biogas power plants are present in over $15 \%$ of poviats with small-scale renewable energy systems, mainly in the Śląskie and Mazowieckie Voivodships. Their total installed capacity accounts for almost $46 \%$ of the installed capacity of all small-scale electricity producers in Poland (the biogas power plants analysed have a considerable installed capacity of $148.5 \mathrm{~kW}$ on average) and for almost $4 \%$ of the installed capacity of all biogas power plants in Poland. The installed capacity of the smallest of the investigated biogas power plants was $75 \mathrm{~kW}$, meaning that all of them are small systems, without any micro facilities present.

An analysis of the micro- and small-renewable energy systems may not omit those using the energy of wind and the energy of solar radiation. They belong to the primary renewable energy sources for electricity production in the world (Boreland and Bagnall, 2008, Tavner, 2008). While in Poland, systems based on these two sources of energy are few: wind power plants and solar power plants are present, respectively, in somewhat more than $5 \%$ and $3 \%$ of the investigated poviats.

Most wind power plants in Poland are large facilities, so it is not surprising that micro and small systems account for only $0.03 \%$ of the installed capacity of all wind power plants in the country. The average installed capacity of the investigated wind power plants was $81.5 \mathrm{~kW}$ and one third of them were micro systems.

Solar power systems (photovoltaic) are still at the early stage of their expansion in Poland. The systems are generally relatively small. Those analysed in the research account for over one-fifth of the installed power of all photovoltaic cells in the country. The average installed capacity of micro and small solar power systems $(36.2 \mathrm{~kW})$ is the lowest among all investigated systems and $75 \%$ of them are classified as belonging to the micro category (see Fig. 2). 


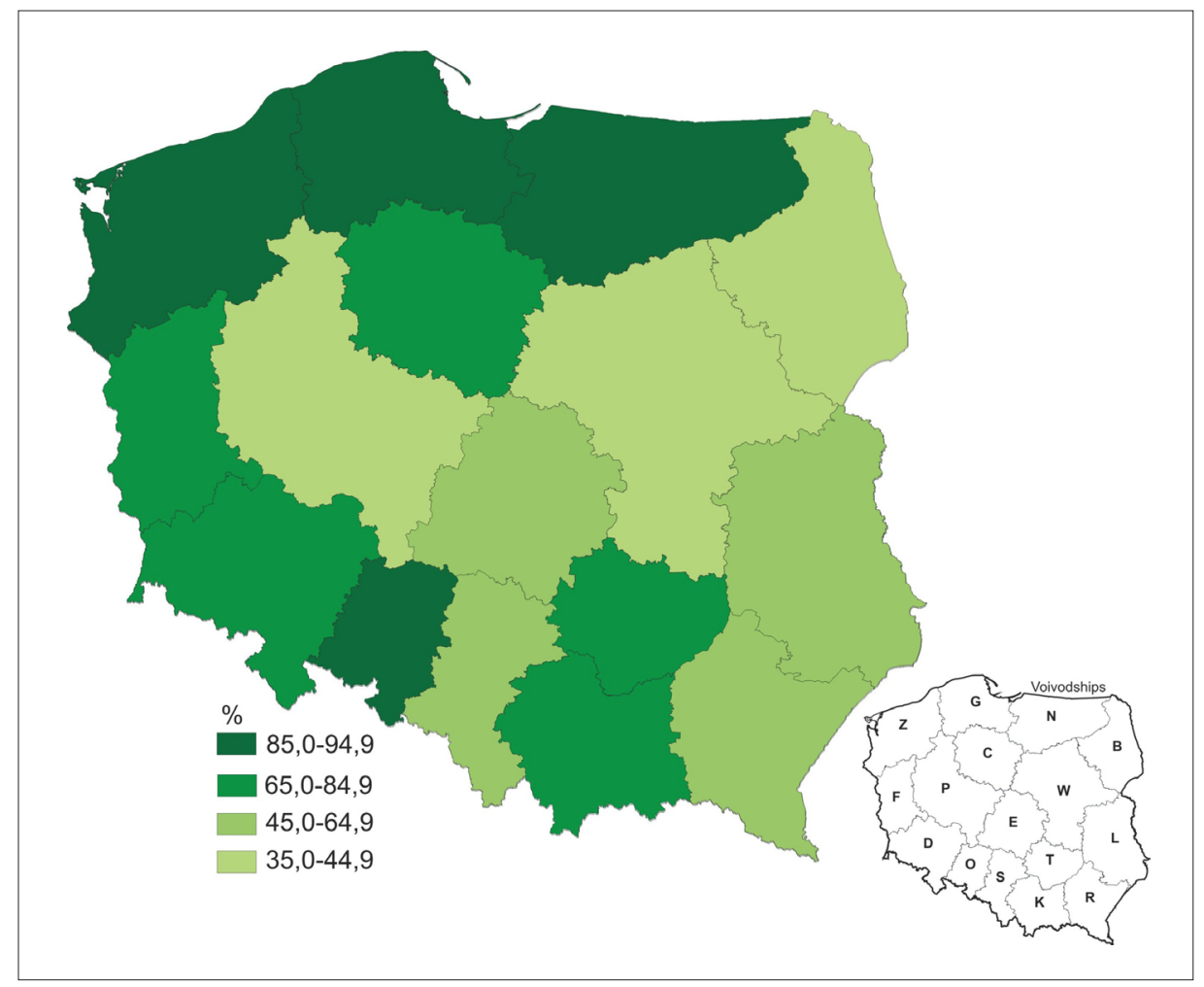

Fig. 1: Rural poviats with micro and small renewable energy systems as percentages of all rural poviats in the voivodships in Poland as of 31 July 2013. Explanation: Voivodships: B-Podlaskie; C-Kujawsko-Pomorskie; D-Dolnośląskie; E-Łódzkie; F-Lubuskie; G-Pomorskie; K-Małopolskie; L-Lubelskie; N-WarmińskoMazurskie; O-Opolskie; P-Wielkopolskie; R-Podkarpackie; S-Ślaskie; T-Świętokrzyskie; W-Mazowieckie; $Z$ - Zachodniopomorskie. Source: developed by the author based on data available at ERO

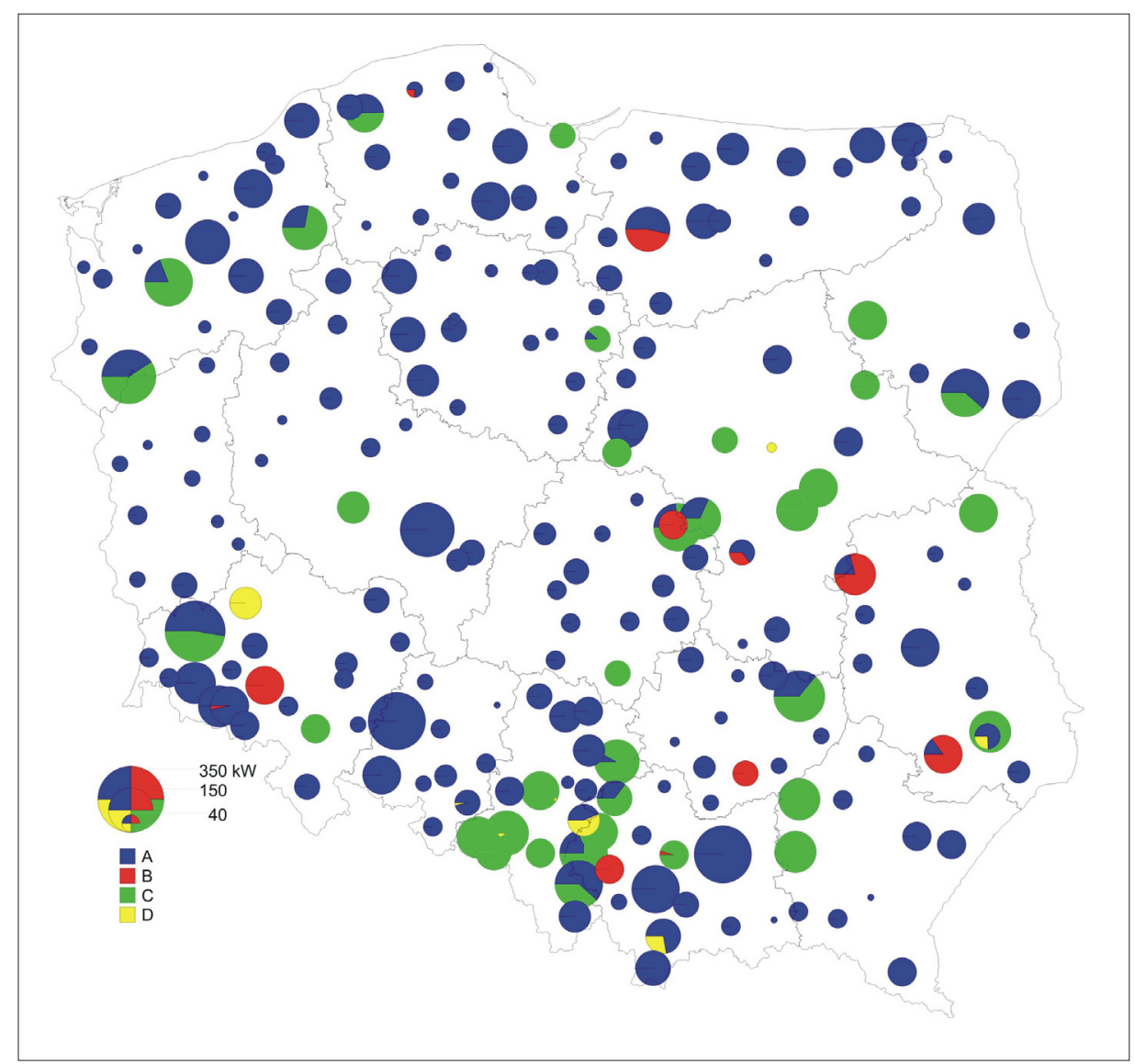

Fig. 2: The structure and the installed capacity of small-scale renewable energy systems in Polish poviats as of 31 July 2013. Explanation: A-hydropower plants; B-wind power plants; $C$-biogas power plants; D-solar power plants. Source: developed by the author based on data available at ERO 
An analysis of the small-scale systems by source of renewable energy shows two trends in their development. One is the prevalence of small hydropower plants following from the development of hydropower generation in areas that have the tradition of harnessing the energy of water (northern and western Poland). The other is the expanding number of systems utilising other energy sources, mainly biogas and the energy of solar radiation. The two sources of energy typically occur in southern Poland, usually in strongly urbanized areas. As far as solar energy is concerned, photovoltaic cells are most common in areas with the highest numbers of companies producing and/ or distributing solar technologies, i.e. in southern Poland (Chodkowska-Miszczuk, Szymańska, 2012).

\section{Solar technologies and the development of distributed generation in Poland - examples of application}

A huge market segment offering opportunities for distributed generation to expand is construction, the most power-intensive sector of the economy, which accounts for over $40 \%$ of final energy consumption in Poland. Special attention should be given to housing, because in 2012 as much as $30 \%$ of final energy consumption in the country was attributed to households (Efektywność wykorzystania energii, 2013). That great amount of energy is mainly used to deliver heat and hot water, which respectively account for $69 \%$ and $15 \%$ of all energy used by housing in Poland (ibid). With the floor area of housing units growing larger and larger and with the spreading use of air conditioning systems, energy consumption may rise still higher.

Among the small-scale renewable energy systems used in the Polish housing sector those based on solar energy technologies are the most common, despite their relatively short history. Systems converting the energy of solar radiation (solar collectors and photovoltaic cells) into usable power are usually located the closest to energy producers and users (Chodkowska-Miszczuk, 2012), are the most environmentally friendly among the power generation technologies, and do not affect the architectural design or aesthetics of the buildings (Chwieduk, 2010). Moreover, projects involving the use of solar radiation energy are eligible for wide financial support from both domestic and EU sources.

In analysing the applicability of solar technology to a building, it is important to consider the building's age, state of repair and architecture. In existing buildings, a number of alterations improving heat circulation and retention must be made for a renewable energy system to be effective. This means that it is much easier to install such systems in new buildings, for instance in single-family houses. A pattern can be observed that in places where the number of new residential buildings is systematically growing (mainly in the suburban areas of large cities (Biegańska, Szymańska, 2013), the number of investments in solar technology projects, mainly solar collectors but increasingly often also photovoltaic systems, is rising too.

Depending on the manner of applying a photovoltaic system to a building, which is determined by whether the building is being designed or already in existence, the Building Integrated Photovoltaics (BIPV) concept or the Building Applied Photovoltaics (BAPV) concept is adopted. The BIPV is one of the most innovative solutions where the photovoltaic system is designed into a building, mainly as an alternative to traditional roof or elevation elements, such as roofing sheets and glass systems. Under the BAPV approach, the building is provided with a non-integrated photovoltaic system (see Fig. 3). The BAPV approach is the most common in the market today; because the BIPV is a relatively new solution, its share in the global photovoltaic market stands at around 1\% (Pietruszko, 2009).

A notable factor in the development of solar energy systems is the high capacity of multi-family buildings in Polish cities to receive them. What makes solar energy technologies (solar collectors and BIPV and BAPV photovoltaic systems) appropriate for the urban built environment that offers few opportunities for modifications, is that they intrude the least on the fabric of buildings and are cost-effective (http://www. urbansolplus.eu/pl/urbansolplus-w-polsce).

My own study into housing cooperatives in Bydgoszcz and Torun (the principal cities of the Kujawsko-Pomorskie Voivodship) has shown that installing solar collectors, photovoltaic cells and heat pumps, as a triad, increases the efficiency of individual devices. These small-scale power systems are applied to meet tenants' demand for energy. Depending on the multi-family building, their total installed capacity may range from 100 to $150 \mathrm{~kW}$. As Kaygusuz et al. (2013) noted in buildings, the energy mixing strategy is very useful for the integration of hybrid renewable energy and the grid energy to meet site power demand. It is worth adding that the systems are mainly installed in multi-family buildings comprising new, modern housing estates (see Fig. 4).

Solar collectors allow hot water to be supplied to the tenants (a modern housing estate has several hundred tenants on average) at much lower cost, an average saving being estimated at $30-40 \%$ annually. Heat pumps considerably lower the cost of heating cost. Photovoltaics is currently in the experimental stage; the most efficient uses of the electrical power that it can generate are still being sought.

Compared with buildings without renewable energy systems, flats in buildings powered by solar collectors, etc., attract much more interest from potential buyers, even though the technology involves additional costs. Solar technologies in multi-family buildings add to the quality of space, and property managers use them for marketing purposes.

\section{Conclusion}

The development of small-scale renewable energy systems provides a range of benefits to environmental protection and the socio-economic development of regions and communities. This research has shown that environmental, social and economic considerations make distributed generation utilising renewable, locally available sources of energy one of the most desirable directions in the development of the power sector in Poland. Unlike the implementation of large power generation facilities, the growing use of small-scale renewable energy systems neither drastically affects the landscape nor changes the way it is perceived, but furthers the socio-economic development of regions and municipalities. Investing in technologies based on renewable energy sources brings passive income and guarantees that the steadily increasing demand for power among the population will be satisfied (not least through the development of prosumer power generation).

Distributed generation in Poland is at the initial stage of its development. One of the key characteristics of distributed generation is the presence of small-scale renewable energy systems (up to $200 \mathrm{~kW}$ of installed capacity). Among these, 


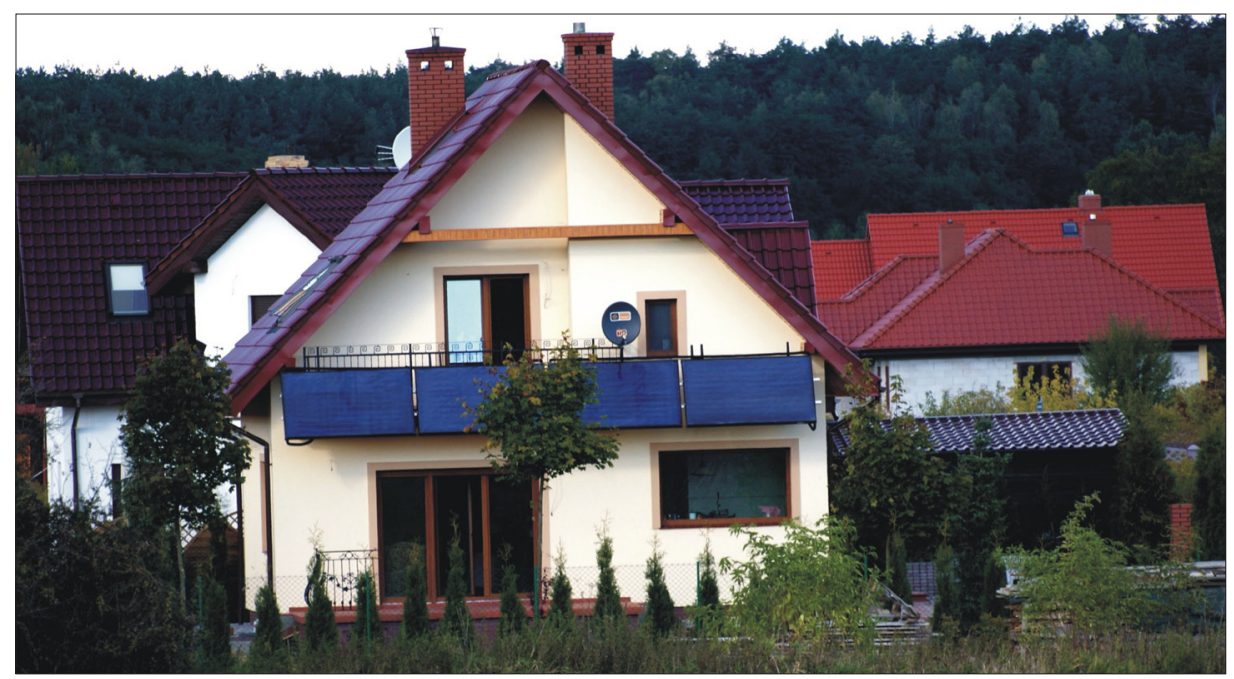

Fig. 3: A single family-house with solar collectors in Czarnowo - a suburban area of the Bydgoszcz-Torun agglomeration (Kujawsko-Pomorskie Voivodship) - an example of the BAPV system. Source: author

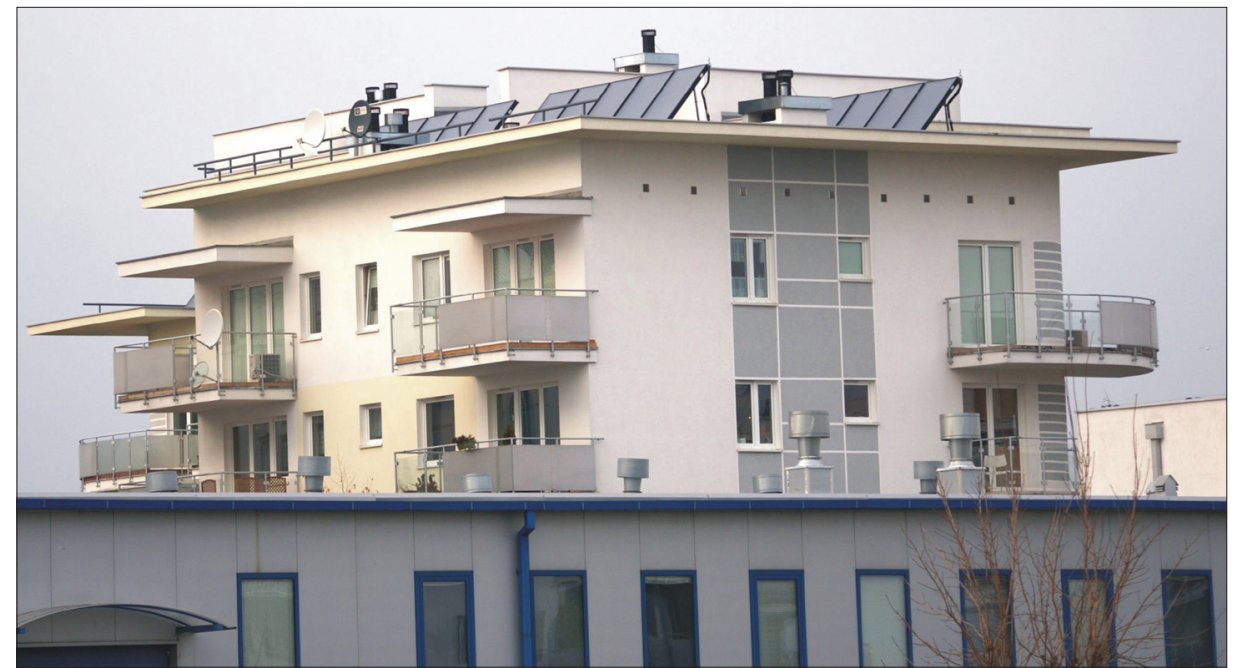

Fig. 4: A multi-family building with solar collectors managed by Spótdzielnia Mieszkaniowa "Budowlani" in Bydgoszcz (Kujawsko-Pomorskie Voivodship). Source: author

hydropower plants are the most important, which have been found in $87 \%$ of poviats using small-scale renewable energy systems. Most of the poviats have a long tradition of harnessing water to generate power (northern and western Poland).

Second in the ranking are biogas power plants (using biogas generated at dump sites and sewage treatment plants). These installations occur in more than $15 \%$ of the analysed poviats, mainly in the Śląskie and Mazowieckie Voivodships. The installed capacity of the biogas power plants is relatively high; micro installations (to $40 \mathrm{~kW}$ ) have not been identified. A source of renewable energy whose importance for electricity production in Poland is growing despite a relatively short history of use is solar radiation. The most common are micro photovoltaic systems averaging $36.2 \mathrm{~kW}$ in installed capacity.

According to the research outcomes, distributed generation is of crucial importance to the housing sector. The most frequent source of renewable energy used in the sector is solar radiation (converted into energy by solar collectors and photovoltaics cells). Solar energy systems are increasingly being integrated into residential buildings. Their use is more common in areas with growing numbers of new housing estates consisting of single-family houses and multi-family buildings, for instance in the suburban areas of large cities.
Solar energy technologies applied to single-family houses and multi-family buildings improve their standard, so property managers frequently refer to them for marketing purposes.

The global trends in the development of the power generation sector combined with technological, legal and financial factors make it probable that small-scale renewable energy systems will be used increasingly often in Poland. The range of the most promising renewable energy sources has the traditional hydropower plants at one end and increasingly popular solar technologies (photovoltaic cells and solar collectors) at the other.

It must be mentioned that this study generates future research in this area. There is a need for further interdisciplinary research on distributed generation and development of small-scale renewable energy systems in Poland. The information on the structure and the installed capacity of small-scale renewable energy systems in Poland, which are included in this article, determine the future research related to directions for the development of the energy sector in Poland. This issue requires further studies especially in the context of the deficient supply of electricity in Poland. Deficits of electricity supply will be particularly noted in the rural areas of eastern Poland (the 
most depopulated area of the country). In this case, the most appropriate solution is the development of distributed generation based on locally-available energy sources.

\section{Acknowledgements}

I have a gratitude for Professor Daniela Szymańska from Department of Urban Studies and Regional Development at the Faculty of Earth Sciences from Nicolaus Copernicus University in Torun for her help during writing this paper. The paper was written thanks to the financial support within a grant for young researchers from Faculty of Earth Sciences, Nicolaus Copernicus University, No. 1695-G.

\section{References:}

AALBERS, R., SHESTALOVA, V., KOCSIS, V. (2013): Innovation policy for directing technical change in the power sector. Energy Policy, Vol. 63, p. 1240-1250.

ACKERMANN, T., ANDERSSON, G., SÖDER, L. (2001): Distributed generation: a definition. Electric Power Systems Research, Vol. 57, p. 195-204.

AKOREDE, M. F., POURESMAEIL, H. E. (2010): Distributed energy resources and benefits to the environment. Renewable and Sustainable Energy Reviews, Vol. 14, p. 24-734.

ALANNE, K., SAARI, A. (2006): Distributed energy generation and sustainable development. Renewable and Sustainable Energy Reviews, Vol. 10, No. 6, p. 539-558.

BAŃKOWSKI, T., ŻMIJEWSKI, K. (2012): Analiza możliwości i zasadności wprowadzenia mechanizmów wsparcia gazowych mikroinstalacji kogeneracyjnych wsparcie energetyki rozproszonej-energetyka społeczna, Warszawa, Instytut im. E. Kwiatkowskiego, grudzień 2012. [online]. [cit. 04.09.2013]. Available at: http://www. forumfree.pl/uploads/raport_mikrokogeneracja.pdf

BARRY, M., CHAPMAN, R. (2009): Distributed small-scale wind in New Zealand: Advantages, barriers and policy support instruments. Energy Policy, Vol. 37, p. 3358-3369.

BASAK, P., CHOWDHURY, S., HALDERNEEDEY, S., CHOWDHURY, S.P. (2012): A literature review on integration of distributed energy resources in the perspective of control, protection and stability of micro grid. Renewable and Sustainable Energy Reviews, Vol. 16, p. 5545-5556.

BELL, P., CLOKE, P. (1990): Concepts of privatization and deregulation. In: Bell, P., Cloke, P. [eds.]: Deregulation and transport: Market forces in the modern world. London, David Fulton Publishers, p. 3-27.

BIEGAŃSKA，J., SZYMAŃSKA，D. (2013): The scale and the dynamics of permanent migration in rural and peri-urban areas in Poland - some problems. In: Szymańska, D., Chodkowska-Miszczuk, J. [eds.]: Bulletin of Geography. Socio-economic Series, No. 21. Toruń Nicolaus Copernicus University Press, p. 21-30.

Biogazownie rolnicze (2013): Abios: Agricultural biogas system. [online]. [cit. 02.08.2013]. Available at: http:// biogazownierolnicze.pl/

BORELAND, M., BAGNALL, D. (2008): Photovoltaic technologies. Energy Policy, Vol. 36, p. 4390-4396.

CARLEY, S. (2009): Distributed generation: an empirical analysis of primary motivators. Energy Policy, Vol. 37, p. $1648-1659$.
CHAMBERS, A. (2001): Distributed generation: a nontechnical guide. Tulsa, PennWell, $283 \mathrm{pp}$.

CHODKOWSKA-MISZCZUK, J. (2012): Obszar turystyczny Dolina Zielawy w kontekście wykorzystania energii słonecznej. Studia Ekonomiczne i Regionalne, Vol. 5, No. 2, p. 112-118.

CHODKOWSKA-MISZCZUK, J., SZYMAŃSKA, D. (2011): Update of the review: Cultivation of energy crops in Poland against socio-demographic factors. Renewable and Sustainable Energy Reviews, Vol. 15, No. 9, p. 4242-4247.

CHODKOWSKA-MISZCZUK, J., SZYMAŃSKA, D. (2012): Technologie słoneczne szansą promocji regionu? Polska Energetyka Słoneczna. Warszawa, Polskie Towarzystwo Energetyki Słonecznej-ISES, Vol. 1-4, p. 63-68.

CHWIEDUK, D. (2010): Solar energy use for thermal application in Poland. Polish Journal of Environmental Studies, Vol. 19, p. 473-477.

CIRONE, A. E., URPELAINEN, J. (2013): Political market failure? The effect of government unity on energy technology policy in industrialized democracies. Technovation, Vol. 33, p. 333-344.

Decentralised Energy Systems (2010): European Parliament Directorate General for Internal Policies, Policy Department Economic and Scientific Policy A. [online] [cit. 03.03.2014]. Available at: http://www.europarl. europa.eu/RegData/etudes/etudes/join/ 2010/440280/ IPOL-ITRE_ET\%282010\%29440280_EN.pdf

DELMAS, M., MONTES-SANCHO, M. J. (2011): U.S. state policies for renewable energy: context and effectiveness. Energy Policy, Vol. 39, p. 2273-2288.

Directive 2009/73/EC of The European Parliament and of The Council of 13 July 2009 concerning common rules for the internal market in natural gas and repealing Directive 2003/55/EC.

Directive 2009/72/EC of The European Parliament and of The Council of 13 July 2009 concerning common rules for the internal market in electricity and repealing Directive 2003/54/EC.

DONDI, P., BAYOUMI, D., HAEDERLI, C., JULIAN, D., SUTER, M. (2002): Network integration of distributed generation. Journal of Power Sources, Vol. 106, p. 1-9.

Efektywność wykorzystania energii w latach 2001-2011. Informacje i opracowania statystyczne. Warszawa, GUS, 2013.

DONG, C. G. (2012): Feed-in tariff vs. renewable portfolio standard: an empirical test of their relative effectiveness in promoting wind capacity development. Energy Policy, Vol. 42, p. 476-485.

EGHTEDARPOUR, N, FARJAH, E. (2012): Control strategy for distributed integration of photovoltaic and energy storage systems in DC micro-grids. Renewable Energy, Vol. 45, p. 96-110.

EL-KHATTAM, W., SALAMA, M. M. A. (2004): Distributed generation technologies, definitions and benefits. Electric Power Systems Research, Vol. 71, p. 119-128.

Encouraging Renewable Energy Development: A Handbook For International Energy Regulators, United States Agency for International Development, January 2011. [online]. [cit. 03.03.2014]. Available at: http://www.naruc. 
org/international/Documents/NARUC\%20-\%20RES\%20 Handbook \%20-\%20FINAL\%20FULL\%20VERSION\%20 03\%2004\% 2011rev\%20again.pdf.

Energetyka rozproszona 2011. Warszawa, Instytut na rzecz Ekorozwoju, Instytut Energii Odnawialnej.

Energy Regulatory Office (2013): Energy Regulatory Office website [online] [cit. 31.07.2013] Available at: www.ure. gov.pl

FRANTÁL, B. KUNC, J. (2011): Wind turbines in tourism landscapes: Czech experience. Annals of Tourism Research, Vol. 38, No. 2, p. 499-519.

GORDIJN, J., AKKERMANS, H. (2007): Business models for distributed generation in a liberalized market environment. Electric Power Systems Research, Vol. 77, p. 1178-1188.

HERRAN, D. S., NAKATA, T. (2012): Design of decentralized energy systems for rural electrification in developing countries considering regional disparity. Applied Energy, Vol. 91, p. 130-145.

HIREMATH, R. B., SHIKHA, S., RAVINDRANATH, N. H. (2007): Decentralized energy planning; modeling and application - a review. Renewable and Sustainable Energy Reviews, Vol. 11, p. 729-752.

HULL, A. (1995): Local strategies for renewable energy. Policy approaches in England and Wales. In: Land Use Policy, Vol. 12, p. 7-16.

JEBARAJ, S., INIYAN, S. (2006): A review of energy models. Renewable and Sustainable Energy Reviews, Vol. 10, p. 281-311.

JIAYI, H., XURONG, J. C. (2008): A review on distributed energy resources and MicroGrid. Renewable and Sustainable Energy Reviews, Vol. 12, p. 2465-2476.

KAYGUSUZ, A., KELES, C., BAYKANT ALAGOS, B., KARABIBER, A. (2013): Renewable energy integration for smart sites. In: Energy and Buildings, Vol. 64, p. 456-462.

KLOSE, F., KOFLUK, M., LEHRKE, S., RUBNER, H. (2010): Toward a distributed - power world. Renewables and smart girds will reshape the energy sector. The Boston Consulting Group, June 2010. [online] [cit. 18.11.2013] Available at: http://www.bcg.com/documents/file51254.pdf.

LOVINS, A. B., DATTA, E. K., FEILER, T., RÁBAGO, K. R., SWISHER, J. N., LEHMANN, A., WICKER, K. (2002): Small is profitable. The hidden economic benefits of making electrical resources the right size. Snowmass, Rocky Mountain Institute.

LUCHTER, L. (2000): Rozwój i uwarunkowania przedsiębiorczości w zakresie wykorzystania odnawialnych źródeł energii w Polsce. Prace Geograficzne, Vol. 106. Kraków, Instytut Geografii Uniwersytet Jagielloński, p. 99-117.

LUCHTER, L. (2001): Proces deregulacji elektroenergetyki w Polsce na tle przemian strukturalnych tego sektora w krajach Unii Europejskiej. In: Zioło, Z. [ed.]: Prace Komisji Geografii Przemysłu, Problemy przemian struktur przemysłowych w procesie wdrażania reguł gospodarki rynkowej, Vol. 3. Warszawa-Kraków-Rzeszów, Komisja Geografii Przemysłu PTG, Wydział Ekonomiczny UMCS w Lublinie Filia w Rzeszowie, p. 99-113.

MISKINIS, V., NORVAISA, E., GALINIS, A., KONSTANTINAVICIUTE, I. (2011): Trends of distributed generation development in Lithuania. Energy Policy, Vol. 39, p. 4656-4663.
MORIARTY, P., HONNERY, D. (2011): Is there an optimum level for renewable energy? Energy Policy, Vol. 39, p. 2758-2753.

NEWCOMB, J., LACY, V., HANSEN, L., BELL, M. (2013): Distributed Energy Resources: Policy Implications of Decentralization. The Electricity Journal, Vol. 26, No. 8, p. $65-87$.

PUPPIM DE OLIVEIRA, J. A. (2009): The implementation of climate change related policies at the subnational level: An analysis of three countries. Habitat International, Vol. 33, p. 253-259.

PECAS LOPES, J. A., HATZIARGYRIOU, N., MUTALE, J., DJAPIC, P., JENKINS, N. (2007): Integrating distributed generation into electric power systems: a review of drivers, challenges and opportunities. Electric Power Systems Research, Vol. 77, p. 1189-1203.

PEPERMANS, G., DRIESEN, J., HAESELDONCKX, D., BELMANS, R., D'HAESELEER, W. (2005): Distributed generation: definition, benefits and issues. Energy Policy, Vol. 33, p. 787-798.

PIETRUSZKO, S. M. (2009): Fotowoltaika zintegrowana z budownictwem (BIPV), VI Forum Operatorów Systemów i Odbiorców Energii i Paliw „Bezpieczeństwo energetyczne a nowe kierunki wytwarzania i wykorzystania energii $w$ Warszawie”, 16 października 2009 r., Warszawa.

Polityka energetyczna Polski do 2030 roku. Warszawa, Ministerstwo Gospodarki, Załącznik do uchwały $\mathrm{nr}$ 202/2009 Rady Ministrów z dnia 10 listopada 2009 r.

PURCHALA, K., BELMANS, R., EXARCHAKOS, L., HAWKES, A. D. (2007): Distributed generation and the grid integration issues. Belgium, KULeuven, EUSUSTEL Project. [online] [cit. 17.11.2013] Available at: http://www.eusustel.be/public/documents_publ/WP/ WP3/WP\%203.4.1\%20Distributed\%20generation\%20 and\%20grid\%20integration\%20issues.pdf.

RICHTER, M. (2013): German utilities and distributed PV: How to overcome barriers to business model innovation. Renewable Energy, Vol. 55, p. 456-466.

RUESTER, S., SCHWENEN, S., FINGER, M., GLACHANT, J. M. (2013): A post-2020 EU energy technology policy: Revisiting the Strategic Energy Technology Plan, EUI Working Paper RSCAS, Vol. 39, San Domenico di Fiesole: European University Institute, Robert Schuman Centre for Advanced Studies, Florence School of Regulation.

RYDIN, Y., TURCU, C., AUSTIN, P. (2011): Planning and the challenge of decentralised energy: a co-evolution perspective. [online] [cit. 01.03.2014] Available at: http:// discovery.ucl.ac.uk/1356406/1/1356406.pdf.

SOLOMON, B. D., PASQUALETTI, M. J., LUCHSINGER, D. A. (2006): Energy Geography. In: Gaile, G. L., Willmott, C. J. [eds.]: Geography in America at the dawn of the $21^{\text {st }}$ century. New York, Oxford University Press, p. 302-313.

SUBERU, M. Y., BASHIR, N., ADEFEMI, M., USMAN, U. (2013): Renewable energy distributed electricity generation and microgrid implementation in rural villages: a review. ARPN Journal of Engineering and Applied Sciences, Vol. 8, No. 2, p. 149-156.

Statystyka Elektroenergetyki Polskiej, 2012, Warszawa, ARE. STEENBLIK, R. P., COROYANNAKIS, P. (1995): Reform of coal policies in Western and Central Europe. Energy Policy, Vol. 23, p. 537-553. 
STOKES, L. C. (2013): The politics of renewable energy policies: The case of feed-in tariffs in Ontario, Canada. Energy Policy, Vol. 56, p. 490-500.

TAVNER, P. (2008): Wind Power as a Clean-Energy Contributor. Energy Policy, Vol. 36, p. 4397-4400.

The Future of Carbon Capture and Storage in Europe (2013), Consultative Communication COM 2013 (180) European Commission.

United Press International (2010): IEA wants governments to do more on efficiency. October 11, 2010.

UrbanSolPlus project (2013): UrbanSolPlus project website [online] [cit. 02.08.2013] Available at: http://www. urbansolplus.eu/pl/urbansolplus-w-polsce/

Ustawa z dnia 26 lipca 2013 r. o zmianie ustawy - Prawo energetyczne oraz niektórych innych ustaw (Dz. U. 2013, poz. 984).

VERBRUGGEN, A., FISCHEDICK, M., MOOMAW, W., WEIR, T. (2010): Renewable energy costs, potentials, barriers: conceptual issues. Energy Policy, Vol. 38, p. $850-861$.

VOGEL, P. (2009): Efficient investment signals for distributed generation. Energy Policy, Vol. 37, p. 3665-3672.

WATSON, J. (2004): Co-provision in sustainable energy systems: the case of micro-generation. Energy Policy, Vol. 32, No. 17, p. 1981-1990.

\section{Author's address:}

\section{Dr. Justyna CHODKOWSKA-MISZCZUK}

Department of Urban Studies and Regional Development Faculty of Earth Sciences, Nicolaus Copernicus University Lwowska 1, 87-100 Torun, Poland

e-mail:jchodkow@umk.pl

Initial submission 30 October 2013, final acceptance 14 May 2014

Please cite this article as:

CHODKOWSKA-MISZCZUK, J. (2014): Small-scale renewable energy systems in the development of distributed generation in Poland. Moravian Geographical Reports, Vol. 22, No. 2, p. 34-43. DOI: 10.2478/mgr-2014-0010.
WIĘCKA, A., SANTORSKA, A., ROSOŁEK, K. (2012): Małoskalowe instalacje odnawialnych źródeł energii. Kolektory słoneczne, systemy fotowoltaiczne, małe elektrownie wiatrowe, Instytut Energetyki Odnawialnej. Szkoła Letnia: Zielona energia w twoim domu, Lubiatowo 25-26 lipca 2012 r.

WOLFE, P. (2008): The implications of an increasingly decentralised energy system. Energy Policy, Vol. 36, p. 4509-4513.

WOLSINK, M. (2012): The research agenda on social acceptance of distributed generation in smart grids: Renewable as common pool resources. Renewable and Sustainable Energy Reviews, Vol. 16, p. 822- 835.

WOODMAN, B., BAKER, P. (2008): Regulatory frameworks for decentralised energy. Energy Policy, Vol. 36, p. 4527-4531.

ZAHEDI, A. (1996): Entirely renewable energy - based electricity supply system (small scale and large scale). Renewable Energy, Vol. 9, No. 1-4, p. 913-916.

ZHANG, L., GARI, N., HMURCIK, L. V. (2014): Energy management in a microgrid with distributed energy resources. Energy Conversion and Management, Vol. 78, p. 297-305.

ZHAO, Y., TANG, K. K., WANG, L. (2013): Do renewable electricity policies promote renewable electricity generation? Evidence from panel data. Energy Policy, Vol. 62, p. 887-897. 